University of Nebraska - Lincoln

DigitalCommons@University of Nebraska - Lincoln

Winter 1-6-2020

\title{
Impact and User Observation of Online Journals in Periyar University (PU): An Empirical study
}

Chandran Velmurugan $\mathrm{Dr}$

Librarian and Head Vivekanandha Arts and Science College for Women Veerachipalayam - 637303 ,

Sankari, Salem Dt., Tamil Nadu, murugan73@gmail.com

Follow this and additional works at: https://digitalcommons.unl.edu/libphilprac

Part of the Library and Information Science Commons

Velmurugan, Chandran Dr, "Impact and User Observation of Online Journals in Periyar University (PU): An Empirical study" (2020). Library Philosophy and Practice (e-journal). 3786.

https://digitalcommons.unl.edu/libphilprac/3786 


\title{
Impact and User Observation of Online Journals in Periyar University (PU): An Empirical study
}

\author{
K. RAMESH \\ Ph.D Research Scholar \\ Department of Library and Information Science \\ Periyar University, \\ Salem-636011 \\ and \\ Dr. CHANDRAN VELMURUGAN \\ Librarian and Head, \\ Vivekanandha Arts and Science College for Women \\ Veerachipalayam, Sankari - West (PO), \\ Sankari - TK, Salem - 637 303, India. \\ Email. murugan73@gmail.com
}

\begin{abstract}
This paper has made an attempt to investigate the usage and impact of electronic journals or online journals among the users such as post graduate students, MPhil scholars, and PhD research candidates from the department of School of Social Sciences at Periyar University, Salem, Tamilnadu, India. It found for the analysis the filled questionnaires rate was $83 \%$ and also found among the four departments, Journalism and Mass Communication department has got ranked first with $24 \%$ to fill the questionnaire. The main purpose of this research is to analyze the impact and the utilization of electronic journals which are provided by the University Library to user community. For data analysis, a total of two hundred questionnaires were distributed among the four departments to fill the questionnaire. Out of 200, we received only 166 dully filled questionnaires at the rate $83 \%$. The result shows that the majority of respondents were female with $61.55 \%$ whereas the remaining was male with $38.45 \%$ and the huge number of 73 $(43.97 \%)$ respondents was postgraduate students. The majority of $83(50.0 \%)$ respondents were preferred to use the pdf format out of 166 users of the department of the School of Social Sciences. 73 (43.96\%) user communities were using the electronic journals weekly. Among the 166 respondents, 77 (46.39\%) respondents were using the Internet to access the electronic journals.
\end{abstract}

Keywords: Electronic Journals, Online Journals, e-journals, User survey, Periyar University, Salem, India. 


\section{Introduction}

University is the backbone of higher education all over the world. The University Library facilitates a number of information resources and services to user society to think new knowledge and research. The electronic resources or digital resources are different kinds such as in the form of Electronic conferences, professional and institutional websites, E-books, Ejournals, Databases, CDs/DVDs, audios, videos, courseware, tutorials, guides, manuals, patents, Electronic preprints, and E-Prints, E-Reports, E-Maps, E-Pictures/Photographs, E-Manuscripts, E-Theses and Dissertations, projects, E-Newspaper, Internet/Websites - Listserv, Newsgroups, Subject Gateways, USENET, FAQs, Databases, Datasets, Digital Collections, etc. Hence, among the all the information resources or reading materials, journals play a vital role in recent research and avoid duplication toil of research.

Electronic journals are also known as e-journals or online journals, paperless journals, electronic serials, virtual journals, web journals, networked journals, scholarly electronic journals, digital journals, Zine or ezines, and Internet based journals. Wikipedia (2018) defined as "online journal articles are a specialized form of electronic document: they have the purpose of providing material for academic research and study, and they are formatted approximately like journal articles in traditional printed journals.' Harrods's Librarian's Glossary defined the e-journals as, "it is a journal for which the full end- product is available on optical disc, over a network or in any other electronic form, strictly a journal in which the entire process is carried out electronically." Ashcroft and Langdon (1993) pointed out about the e-journals as "a journals that is provided by any electronic means e.g. Internet or CD-ROM, although not necessary exclusive by electronic means" which is the most common definition. Therefore, this research has been chosen to identify the usage of online journals among the user community of the School of Social Sciences department users in Periyar University as there is no such a study has been conducted to evaluate Electronic Journals so far.

\section{Literature Review}

A number of studies have conducted by many researchers and scholars by different subjects in different periods regarding the Electronic Journals or Online Journals. Hence, only recent researches have been taken into account for this current study. Mane and Kuman (2017) studied their study under the title of, Use of E-Journals among the library patrons: a survey of Indira Group of Institutions, Pune" to identify the understanding of user behavior in terms of usage of electronic journals. The main objective of this study was to know the utilization and frequency of use of e- resources. The study found that the huge number $(52.0 \%)$ of both students and faculty members were highly satisfied with the availability and services of the use of electronic journals in the IGI Library. Patel and Darbar (2017) examined the user survey to know about the awareness of electronic resources amoing the user community of C.K. Shah Vijapurwala Institute of Management (CKSVIM) Library, Vadodara. The results indicated that $35.32 \%$ of the user community use electronic resources daily and $64.26 \%$ of the users stated that e-resources were highly useful.

Nanda (2017) examined the usage and access pattern of electronic journals through faculty members and research scholars at the Veer Surendra Sai University of Technology, Odisha. A 
total of 148 questionnaires were distributed and 115 filled in questionnaires returned. The results showed that the majority of faculty members $(51.78 \%)$ and research scholars $(54.23 \%)$ were using the electronic journals on daily and huge number of $73.21 \%$ of the faculty members and $83.05 \%$ of the research scholars using the online journals which were provided by the University Library for their research purpose. Khan (2016) studied the use and impact of UGC INFONET online journals by the users of Gautam Buddha University. The results revealed that major proportion of users were satisfied in terms of availability of online journals usage. Velmurugan and Umamaheswari (2015) investigated to know about the reading habit of online journals and use of internet in School Libraries in Chennai. The results reflect that the huge number of nearly fifty percent of the users were well aware of the knowledge about electronic journals and well known how to use them. Velmurugan (2013) studied to examine the information seeking behavior of online journals among the undergraduate students of an Engineering College called SIFT in Chennai. The results indicated that more than $77 \%$ of the respondents of SIFT were well known about the awareness of online journals and nearly four percent of them were no idea about the electronic journals. Thanuskodi and Ravi (2011) analyzed the online resources by the PG students and doctoral candidates of Faculty of Arts at the Annamalai University. A total of 200 questionnaires distributed and 180 returned. The results represented that the majority of users were sound knowledge about the electronic information resources and almost $50 \%$ of the respondents access only electronic format and the remaining $40 \%$ of the user community preferred to read print journals.

\section{Profile of the Periyar University}

The Periyar University consists of four districts such as Salem, Namakkal, Dharmapuri, and Krishnagiri and it has been established in $17^{\text {th }}$ September 1997 in Salem. It has ranked 90 ${ }^{\text {th }}$ among Indian Universities by MHRD NIRF in 2018 and has occupied 12(B) and 2f status from the University Grants Commission, New Delhi. This University imparts higher education by way of three modes namely, through its departments of the study and research, the affiliated colleges, and Periyar University Distance Education (PRIDE). This University has Twenty eight (28) departments and 106 affiliated colleges. the affiliated colleges covers, 14 government colleges, 6 constituent colleges, 4 aided colleges, and 82 self-financing colleges, and also 11 community colleges are comes under Periyar University. For the present research, it has been selected only four departments i.e. Sociology, Psychology, Journalism and Mass Communication and History under the School of Social Sciences. Sociology: This department offering programmes such as MA, MPhil, PhD and certificate course in NGO and also Management for Social development (one Year). Psychology: This department offering programmes such as Msc, MPhil, PhD and two supportive courses for other PG programs such as Personality and adjustment to modern life - odd semester, and Psychology for personal professional development - even semester. Journalism and Mass Communication: This department offering programmes such as MA in Journalism and Mass Communication and, MA - Journalism and Mass Communication (Electronic Media 5 years integrated), MPhil, and PhD. History: This department offering programmes such as MA in History, MPhil and PhD Programme. Among the four departments, three departments viz, Sociology, Psychology, Journalism and Mass Communication have established during the year 2008 and the department of History is the recent one which is established in the year 2015. 


\section{Periyar University Central Library Digital Library}

Periyar University Central Library facilitates an excellent online information sources and services to the user community. Providing Digital Library facility is one among the services which are providing in the University Central Library, Periyar University is subscribing online journals for Digital Library and it covers the following online journals and publishers.

- Journal of Educational Research,

- World Bank Economic Review,

- Sage publications' journals,

- Emerald publications

- World Scientific publications

- EBSCO Online database

- American Society of Microbiology (ASM)

- SREL Journal of Information Management journal

Moreover, more than 30 open access journals from well-known publishers such as Wiley online, Nature Publishing Group, DOAJ, Academic journals, Indian Academy of Science (IAS), Indian National Science Academy etc are providing access to the user society.

\section{Statement of the problem}

The current study entitled, "Impact and Use Observation of Online Journals in Periyar University (PU): An Empirical study" and the demand for the research is that the establishment of the School of Social Sciences covering the departments such as sociology, Psychology, Journalism and Mass Communication, and History. This is the inimitable research as there is no such a study has been conducted to evaluate the School of Social Sciences department users in Periyar University and their requirements of information and information seeking behavior on Electronic Journals so far.

\section{Objectives of the Study}

The most important purpose of this current research is to examine the current challenges faced by the library users such as students from PG departments, MPhil scholars, PhD candidates and faculty members who are in the School of Social Sciences at Periyar University in Salem, Tamilnadu. The other objectives are to know the usage of print as well as electronic journals, to observe the frequency of use of library by the users, to examine the frequency of use of EJournals among the users of Physical sciences department in Periyar University. to analyze the time spend on the use of electronic journals, to find out the problems faced while accessing ejournals, to find out the level of satisfaction with usage of e-journals and many more features are discussed. 


\section{Materials and Methods}

Descriptive method was used in this research. For analysis, the data was collected through the questionnaire method. The population sample is the department of the School of Social Sciences which includes Sociology, Psychology, Journalism and Mass Communication and History. A total of two hundred questionnaires were distributed among the four departments to fill the questionnaire. Out of 200 questionnaires, researchers received only 166 dully filled questionnaires at the rate $83 \%$. The category of user community is post graduate students, MPhil students, and Research scholars of the department of the School of Social Sciences. An attempt has been made to execute the analysis of data that the survey method was used as it is the best statistical tool for large population of samples. The study was limited to the faculty members, post graduate students, and research scholars from the department of the School of Social Sciences only. This study is unique and it has been taken into account as survey research since there is no such as a study has been done so far.

\section{Data Analysis}

\section{Distribution of questionnaire}

The questionnaire method was used to evaluate the data and distributed to selected four departments cover Sociology, Psychology, Journalism and Mass Communication and History. A total of two hundred questionnaires were distributed among the four departments to fill the questionnaire. Out of 200 , we received only 166 dully filled questionnaires at the rate $83 \%$. It found among the four departments, Journalism and Mass Communication department has got ranked first with $24 \%$ to fill the questionnaire and the least number of questionnaire filled by History department with $16.50 \%$.

Table 1. Respondents' distribution according to the Department

\begin{tabular}{|c|l|c|c|c|}
\hline \multirow{2}{*}{ S. No } & \multirow{2}{*}{ Department } & \multicolumn{2}{|c|}{ Questionnaire } & Percentage \\
\cline { 3 - 4 } & & Distributed & Returned & \\
\hline 1 & Sociology & 50 & 44 & 22.00 \\
\hline 2 & Psychology & 50 & 41 & 20.50 \\
\hline 3 & JMC & 50 & 48 & 24.00 \\
\hline 4 & History & 50 & 33 & 16.50 \\
\hline \multicolumn{2}{r|r|}{ Total } & 200 & 166 & 83.00 \\
\hline
\end{tabular}

\section{Gender wise distribution}

Table 2 represents the gender wise contribution of respondents during the research. It is seen that the majority of respondents is female with $61.55 \%$ whereas the least number of respondents is male with $38.45 \%$.

Table 2. Respondents' distribution according to Category

\begin{tabular}{|c|l|c|c|}
\hline S. No & \multicolumn{1}{|c|}{ Users Category } & $\begin{array}{c}\text { No. of } \\
\text { Respondents }\end{array}$ & Percentage \\
\hline 1 & Male & 64 & 38.45 \\
\hline
\end{tabular}




\begin{tabular}{|r|l|c|c|}
\hline 2 & Female & 102 & 61.55 \\
\hline & Total & 166 & 100 \\
\hline
\end{tabular}

\section{Different kinds of Users}

Table 3 indicates the different kinds of users who were participated in this present research. The users' categories were divided into four such as PG Students, MPhil scholars, PhD candidates and faculty members. Based on the analysis, the huge number of 73 (43.97\%) respondents were postgraduate students and followed by 43 (25.91\%) of the users were from MPhil scholars. it is found that the small number of $22(13.25 \%)$ respondents were PhD candidates.

Table. 3. Different kinds of users

\begin{tabular}{|c|l|c|c|}
\hline S. No & \multicolumn{1}{|c|}{ Users } & $\begin{array}{c}\text { No. of } \\
\text { Respondents }\end{array}$ & Percentage \\
\hline 1 & Faculty & 28 & 16.87 \\
\hline 2 & PG Students & 73 & 43.97 \\
\hline 3 & MPhil Scholars & 43 & 25.91 \\
\hline 4 & PhD candidates & 22 & 13.25 \\
\hline \multicolumn{2}{|r|}{ Total } & 166 & 100 \\
\hline
\end{tabular}

\section{Age wise distribution}

Table 4 represents the age wise distribution by the user community of four departments. The findings of the study shows that the respondents of age group is between 18-20 were $25.90 \%$ and followed by the between $21-30$ were $34.94 \%$, and $22.29 \%$ of the respondents' age group between $31-40$ were and only $16.87 \%$ of age group were above 41 age. The result indicates that the majority of the respondents' age group was between 21-30 ages.

Table 4. Age wise distribution

\begin{tabular}{|c|l|c|c|}
\hline S. No & \multicolumn{1}{|c|}{ Users Category } & $\begin{array}{c}\text { No. of } \\
\text { Respondents }\end{array}$ & Percentage \\
\hline 1 & $18-20$ & 43 & 25.90 \\
\hline 2 & $21-30$ & 58 & 34.94 \\
\hline 3 & $31-40$ & 37 & 22.29 \\
\hline 4 & Above 41 & 28 & 16.87 \\
\hline \multicolumn{2}{r|}{ Total } & 166 & 100 \\
\hline
\end{tabular}

\section{Preference of journals}

Table 5 shows the analysis of preference of journals to use the documents in the forms such as print, online like pdfs and both forms were measured. This research indicates that almost half of the respondents $(50.61 \%)$ were preferred and willing to access and read the journal articles through online. on the other hand, $18.67 \%$ of the respondents were using print journals, and $30.72 \%$ of the respondents were using both forms of journals. 
Table.5. Preference of journals

\begin{tabular}{|c|l|c|c|}
\hline S. No & \multicolumn{1}{|l|}{ Journals preference } & $\begin{array}{c}\text { No. of } \\
\text { Respondents }\end{array}$ & Percentage \\
\hline 1 & Print form & 31 & 18.67 \\
\hline 2 & Online based & 84 & 50.61 \\
\hline 3 & Both & 51 & 30.72 \\
\hline \multicolumn{2}{r|}{ Total } & 166 & 100 \\
\hline
\end{tabular}

\section{Preferred format of e-journals}

Table 6 represents the respondents' preference of the format of the electronic journals which are provided by the University Central Library. The formats are PDF, HTML, SGML, ASCII, and MS Word etc. The majority of $83(50.0 \%)$ respondents were preferred to use the pdf format out of 166 users of the department of the School of Social Sciences. It is counted the least number of respondents using the various formats and found six percent of the respondents were using the ASCII format to access the electronic journals.

Table. 6. Preferred format of e-journals

\begin{tabular}{|c|l|c|c|}
\hline S. No & Journals preference & $\begin{array}{c}\text { No. of } \\
\text { Respondents }\end{array}$ & Percentage \\
\hline 1 & PDF & 83 & 50.00 \\
\hline 2 & HTML & 24 & 14.46 \\
\hline 3 & SGML & 12 & 7.23 \\
\hline 4 & ASCII & 6 & 3.61 \\
\hline 5 & MS Word & 41 & 24.70 \\
\hline \multicolumn{2}{r|}{ Total } & 166 & 100 \\
\hline
\end{tabular}

\section{Frequency use of Electronic journals}

The frequency based usage and utilization of electronic journals by the respondents of the School of Social Sciences. Table 7 depicts that the frequency such as every day, weekly, fortnightly, monthly, and rarely. It is seen that the majority of 73 (43.96\%) user communities were using the electronic journals weekly, 26.51 percent of the user society were using the online journals in the frequency of every day, and $14.47 \%$ of the users were using fortnightly, 16 respondents were using the online journals in the monthly basis, and only 6 (5.41\%) of the respondents were using electronic journals irregularly.

Table. 7. Frequency use of Electronic journals

\begin{tabular}{|c|l|c|c|}
\hline S. No & \multicolumn{1}{|c|}{ Frequency } & $\begin{array}{c}\text { No. of } \\
\text { Respondents }\end{array}$ & Percentage \\
\hline 1 & Every day & 44 & 26.51 \\
\hline 2 & Weekly & 73 & 43.96 \\
\hline 3 & Fortnightly & 24 & 14.47 \\
\hline 4 & Monthly & 16 & 9.65 \\
\hline
\end{tabular}




\begin{tabular}{|r|l|c|c|}
\hline 5 & Rarely & 9 & 5.41 \\
\hline & Total & 166 & 100 \\
\hline
\end{tabular}

\section{Place of using Electronic journals}

It is inferred from the below table 8 in terms of the place of using the online journals and other electronic resources by the user community where they are leaning and accessing the electronic journals. The accessing places were identified through the questionnaire and noted that Digital Library, Department, Computer Lab, and private Internet Café. It is analyzed among the 166 respondents, 77 (46.39\%) respondents were using the Internet to access the electronic journals, and followed by $30.72 \%$ of the users were accessing the online journals in the Digital Library and few $(5.42 \%)$ of the respondents were using Internet to access online resources in the Internet Café.

Table.8. Location of using Electronic journals

\begin{tabular}{|c|l|c|c|}
\hline S. No & \multicolumn{1}{|c|}{ Frequency } & $\begin{array}{c}\text { No. of } \\
\text { Respondents }\end{array}$ & Percentage \\
\hline 1 & Digital Library & 51 & 30.72 \\
\hline 2 & Department & 29 & 17.47 \\
\hline 3 & Computer Lab & 77 & 46.39 \\
\hline 4 & Internet Café & 9 & 5.42 \\
\hline \multicolumn{2}{r|}{ Total } & 166 & 100 \\
\hline
\end{tabular}

\section{Purpose of using Electronic journals}

It is seen from the below table 9 indicates that how the respondents are using the electronic journals and what are the reasons to access the online journals. Hence, the analysis shows that the huge number of $65(39.15 \%)$ respondents was using the online journals for their research papers preparation for publication. 24.70 percent of the respondents were using for the purpose of assignments to submit in time, and 14.46 percent of the respondents were using for academic purpose ie to learn about the subjects. it is found the only few $(9.04 \%)$ of the respondents were using the online journals to update their knowledge now and then.

Table.9. Purpose of using Electronic journals

\begin{tabular}{|c|l|c|c|}
\hline $\begin{array}{c}\text { S. } \\
\text { No }\end{array}$ & \multicolumn{1}{|c|}{ Purpose } & $\begin{array}{c}\text { No. of } \\
\text { Respondents }\end{array}$ & Percentage \\
\hline 1 & For academic purpose & 24 & 14.46 \\
\hline 2 & For seminars and conference & 21 & 12.65 \\
\hline 3 & For assignments & 41 & 24.70 \\
\hline 4 & For articles preparation & 65 & 39.15 \\
\hline 5 & For updating knowledge & 15 & 9.04 \\
\hline \multicolumn{2}{|r|r|}{ Total } & 166 & 100 \\
\hline
\end{tabular}




\section{Time spend using Electronic Journals}

Table 10 depicts the time spending on accessing the Electronic Journals by the user community. It is examined that the maximum number of users $(51.82 \%)$ preferred to access the Electronic journals between 1- 2 hours, and followed by $24.69 \%$ of the respondents were using to access online journals within 'an hour', and the small percentage of (9.04\%) respondents were using Internet to access the electronic journals above 3 hours.

Table.10. Time spend using Electronic Journals

\begin{tabular}{|c|l|c|c|}
\hline S. No & \multicolumn{1}{|c|}{ Frequency } & $\begin{array}{c}\text { No. of } \\
\text { Respondents }\end{array}$ & Percentage \\
\hline 1 & An hour & 41 & 24.69 \\
\hline 2 & Between 1-2 hours & 86 & 51.82 \\
\hline 3 & Between 2-3 hours & 24 & 14.45 \\
\hline 4 & Above 3 hours rral & 15 & 9.04 \\
\hline \multicolumn{2}{|r|}{ Total } & 166 & 100 \\
\hline
\end{tabular}

\section{Problems faced while accessing Electronic Journals}

It shows table 10 regarding the problems faced by the respondents while using internet to access the electronic journal. The problems such as network connection, downloading papers, lack of training, and overload information etc. The analysis indicates that among the 166 respondents, the huge number of $62(37.35 \%)$ respondents felt that there is no proper training and lack of knowledge in terms of accessing online journals, and followed by 27.71 percent of the respondents though that the information overload. 21.08 percent of the users felt that taking too much time to getting the paper to download, and $13.86 \%$ of the respondents indicates that there is no proper network facility and connectivity to access the electronic journals during the research period.

Table.10.Problems faced while acceding Electronic Journals

\begin{tabular}{|c|l|c|c|}
\hline $\begin{array}{c}\text { S. } \\
\text { No }\end{array}$ & \multicolumn{1}{|c|}{ Facing difficulties } & $\begin{array}{c}\text { No. of } \\
\text { Respondents }\end{array}$ & Percentage \\
\hline 1 & Connectivity problem & 23 & 13.86 \\
\hline 2 & Getting delay for downloading & 35 & 21.08 \\
\hline 3 & Overload of information & 46 & 27.71 \\
\hline 4 & $\begin{array}{l}\text { Lack of knowledge and training to } \\
\text { access e-journals }\end{array}$ & 62 & 37.35 \\
\hline \multicolumn{2}{|r|}{ Total } & 166 & 100 \\
\hline
\end{tabular}

\section{Level of satisfaction}

Researchers asked the question to the user community during the research period regarding the satisfaction level in terms of online journals availability and services. The range of satisfaction levels were 'Excellent', 'Good,' 'Moderate', and 'No opinion'. Table 11 represents that among the 166 user community who were involved in this present research, the majority of 68 (40.96\%) respondents thought that the availability and their services of the central library were 'Excellent' 
satisfaction and followed by $28.31 \%$ of the user society felt 'Moderate' satisfaction, 21.69 percent of them were 'Good,' and few of the (9.04\%) respondents felt 'No opinion'.

Table.11. Level of satisfaction

\begin{tabular}{|c|l|c|c|}
\hline $\begin{array}{c}\text { S. } \\
\text { No }\end{array}$ & \multicolumn{1}{|c|}{ Satisfaction Level } & $\begin{array}{c}\text { No. of } \\
\text { Respondents }\end{array}$ & Percentage \\
\hline 1 & Excellent & 68 & 40.96 \\
\hline 2 & Good & 36 & 21.69 \\
\hline 3 & Moderate & 47 & 28.31 \\
\hline 4 & No opinion & 15 & 9.04 \\
\hline \multicolumn{2}{r|}{ Total } & 166 & 100 \\
\hline
\end{tabular}

\section{Findings}

The research concluded with selected findings based on the data and analysis and they are listed below.

- It found for the analysis the filled questionnaires rate was $83 \%$ and also found among the four departments, Journalism and Mass Communication department has got ranked first with $24 \%$ to fill the questionnaire.

- The majority of respondents were female with $61.55 \%$ whereas the remaining was male with $38.45 \%$ and the huge number of $43.97 \%$ of respondents was postgraduate students.

- The majority $50.0 \%$ of respondents were preferred to use the pdf format out of 166 users of the department of the School of Social Sciences.

- It examined the majority of $43.96 \%$ user communities were using the electronic journals weekly.

- It analyzed among the 166 respondents $46.39 \%$ of respondents were using the Internet to access the electronic journals.

- It investigated the huge number of 65 (39.15\%) respondents was using the online journals for their research papers preparation for publication.

- Among the 166 respondents, the huge number of $37.35 \%$ respondents felt that there was no proper training and lack of knowledge in terms of accessing online journals.

- The majority of $40.96 \%$ respondents thought that the availability and their services of the central library were 'Excellent' satisfaction. 


\section{Reference}

1. Ashcroft, Linda and Langdon, Colin. (1993). Electronic journals and university library collections. Collection Building, 18(3), 105-113.

2. Electronic journals, Wikipedia (2018), https://en.wikipedia.org/wiki/Electronic_journal, accessed on 24.10.2018.

3. Harrods Librarian Glossary and Reference Book (10th ed.) (2005).

4. Khan, Javed. (2016). Use of UGC INFONET e-journals consortium by the users of Gautam Buddha University: A case study. International Journal of Academic Library and Information Science, 4 (6), 154-157.

5. Mane, M.B and Kuman, MN. (2017). Use of E-journals Among the Library Patrons: A Survey of Indira Group of Institutes, Pune. International Research: Journal of Library \& Information Science, 7 (2), 260-274.

6. Nanda, A. (2017). Use and Awareness of E-journals by the Faculty and Research Scholars of Veer Surendra Sai University of Technology. DESIDOC Journal of Library \& Information Technology, 37(4), 274-280.

7. Patel, KM and Darbar, M. (2017). Availability and Use of E-Resources by Users of CKSVIM Library, Vadodara: A Study. International Research: Journal of Library \& Information Science, 7 (4), 675-689.

8. Thanuskodi, S. and Ravi, S. (2011). Use of Digital Resources by Faculty and Research Scholars of Manonmaniam Sundaranar University, Tirunelveli. DESIDOC Journal of Library \& Information Technology, 31(1), 25-30.

9. Velmurugan, C (2013). Awareness and Usage of Electronic Journals among Undergraduate Students in an Engineering College Central Library, Chennai, Tamilnadu: A Case Study, Journal of Advances in Library and Information Science, 2(3), 124-129.

10. Velmurugan, $\mathrm{C}$ and Umamaheswari, V. (2015). Reading Habits in the Electronic Era and the Use of Internet in School Libraries, Chennai, Tamilnadu, India, Journal of Advances in Computational Sciences and Information Technology, 3(1), 59-65. 